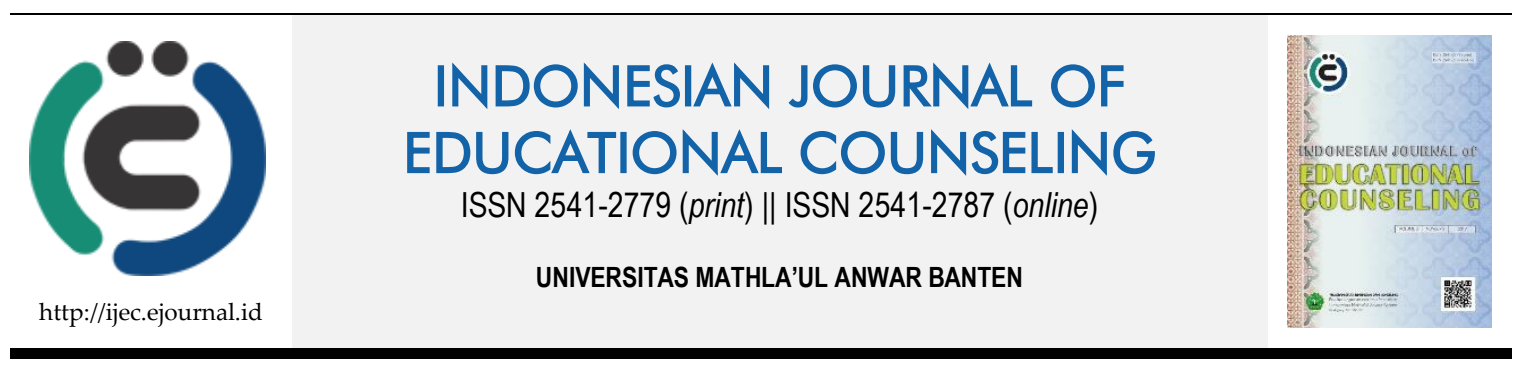

Research Based Article

\title{
Pengaruh Layanan Konseling Kelompok terhadap Self- Efficacy Siswa yang Mengalami Kesulitan Belajar
}

\author{
I Wayan Dharmayana ${ }^{1}$, Meita Pratami² \\ 1, 2 Universitas Bengkulu
}

\begin{tabular}{|c|c|}
\hline Article History & ABSTRACT \\
\hline $\begin{array}{l}\text { Received: } 25.03 .2019 \\
\text { Received in revised form: } \\
\text { 01.04.2019 } \\
\text { Accepted: } 10.04 .2019 \\
\text { Available online: } 05.08 .2019\end{array}$ & $\begin{array}{l}\text { THE EFFECT OF GROUP COUNSELING SERVICES ON SELF-EFFICACY OF THE } \\
\text { STUDENT WITH LEARNING DIFFICULTIES. A student with learning difficulties } \\
\text { tends to have low self-efficacy in the learning process. The student should be } \\
\text { encouraged to have high self-efficacy. Higher Self-efficacy shows a more persistent } \\
\text { attitude, engage in learning, not worry, and not experience pressure in dealing with } \\
\text { problems. This study aims to describe the effect of group counseling services on the } \\
\text { self-efficacy of students with learning difficulties in students in Junior High School. } \\
\text { This research is a quasi-experimental with one group pre-test-post-test design. The } \\
\text { subjects of this were eight students in class VIII. Data collected by AUM PTSDL to } \\
\text { found the student with a Learning difficulty and self-efficacy questionnaires to } \\
\text { measure the self-efficacy of the student. The results showed that the students' self- } \\
\text { efficacy in learning difficulties increased after treatment with the group counseling } \\
\text { service. It has shown from the results of differences test between pretest and postest } \\
\text { with Wilcoxon Signed Rank Test (Z test) value }=-2,527 \text { ( } p<0,05) \text {. This means that } \\
\text { there was a significant differences self-efficacy of students with learning difficulties } \\
\text { before and after group counseling services treatment to the subject. The results } \\
\text { showed that students' self-efficacy increase after treatment. }\end{array}$ \\
\hline & KEYWORDS: Group Counseling Services, Learning Difficulties, Self-Efficacy. \\
\hline
\end{tabular}

DOI: 10.30653/001.201933.106

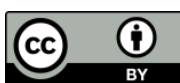

This is an open access article distributed under the terms of the Creative Commons Attribution 4.0 International License, which permits unrestricted use, distribution, and reproduction in any medium, provided the original work is properly cited. (c) 2019 I Wayan Dharmayana, Meita Pratami.

\section{PENDAHULUAN}

Pendidikan bagi kehidupan umat manusia merupakan kebutuhan mutlak yang harus dipenuhi sepanjang hayat lebih-lebih di era Revolusi Industri 4.0. Tanpa pendidikan adalah mustahil suatu kelompok manusia dapat hidup berkembang sejalan perkembangan ilmu dan teknologi dan aspirasi (cita-cita) untuk maju, sejahtera dan bahagia menurut konsep pandangan hidup peserta didik. Proses pendidikan pada hakekatnya adalah belajar, yang melibatkan perubahan mental sehingga menghasilkan perubahan-perubahan dalam bersikap (Ihsan, 2008, p. 2). Pelaksanaan pendidikan sesuai dengan tujuan pendidikan nasional yang tercantum dalam Undang-Undang No 20 Tahun 2003 Bab 2 Pasal 3 yaitu: Untuk mengembangkan potensi siswa agar menjadi manusia

${ }^{1}$ Corresponding author's address: Program Studi Bimbingan dan Konseling, Universitas Bengkulu; Jl. WR. Supratman, Kandang Limun, Muara Bangka Hulu, Bengkulu 38371, Indonesia; Email: dharmayana@unib.ac.id 
yang beriman dan bertakwa kepada Tuhan Yang Maha Esa, berakhlak mulia, sehat, berilmu, cakap, kreatif, mandiri, dan menjadi warga negara yang demokrasi serta bertanggung jawab (Gunawan, 2014, p. 5).

Pada seluruh proses pendidikan, belajar merupakan kegiatan inti pendidikan sebagai batuan dalam perkembangan melalui kegiatan belajar. Peserta didik merupakan unsur penting dalam suatu proses belajar mengajar. Secara psikologis belajar dapat diartikan sebagai proses memperoleh perubahan tingkah laku (baik kognitif, afektif maupun psikomotor) berkat pengalaman dan latihan untuk memperoleh respons yang diperlukan dalam interaksi dengan lingkungan secara efisien (Yusuf \& Nurihsan, 2010, p. 222).

Belajar merupakan suatu proses seseorang untuk mencapai hasil belajar. Dalam rangka pengembangan potensi diri, setiap siswa mempuyai kemampuan yang berbedaberbeda. Kemampuan siswa untuk belajar secara terus-menerus memberikan sumbangan bagi pengembangan berbagai gaya hidup. Setiap guru berkeinginan agar siswa memperoleh hasil yang optimal dalam belajarnya. Namun pada kenyataannya, tidak semua siswa mendapatkan hasil yang diharapkan. Prestasi belajar yang memuaskan dapat diraih oleh setiap peserta didik jika dapat belajar secara wajar, dan terhindar dari berbagai hambatan dan kesulitan. Sebaliknya banyak hambatan dialami oleh peserta didik tertentu sehingga mereka mengalami kesulitan belajar.

Kesulitan belajar adalah suatu kondisi siswa tidak dapat belajar secara wajar, karena adanya ancaman, hambatan ataupun gangguan dalam belajar. Oleh karena itu harus ada tindakan atau upaya untuk membantu siswa dalam mengatasi hambatan yang mungkin dialami oleh siswa dalam belajar (Djamarah, 2015). Kesulitan belajar siswa ditunjukkan oleh adanya hambatan-hambatan tertentu untuk mencapai hasil belajar sehingga pada akhirnya dapat menyebabkan prestasi belajar yang dicapainya berada di bawah semestinya.

Banyak sekali masalah yang berkaitan dengan kesulitan belajar yang dialami oleh peserta didik. Kita sering menemukan siswa seperti malas, mudah putus asa yang merupakan bagian dari masalah belajar siswa. Permasalahan yang berkaitan dengan kesulitan belajar siswa ditandai dengan adanya hasil belajar yang rendah di bawah ratarata, nilai yang dicapai di bawah potensi yang dimilikinya,banyak siswa yang intelegensinya tingg tetapi memiliki hasil belajar yang rendah (underachiever), hasil yang dicapai tidak seimbang dengan usaha yang dilakukan, lambat dalam melakukan tugastugas kegiatan belajarnya sebaliknya siswa yang memeliki rata-rata intelegensi normal tetapi mendapat hasil belajarnya baik daripada siswa yang memiliki intelegensi tinggi (Djamarah 2015). Menurut Syah (2007) penyebab kesulitan belajar dibagi dua faktor yaitu faktor intern siswa dan faktor ekstern pesera didik. Faktor intern yang bersifat kognitif yaitu rendah intelengensinya, bersifat afektif di antaranya labilnya emosi, sangat rendah keyakinan dan kepercayaan dirinya (efikasi dirinya), dan yang bersifat psikomotor di antaranya gangguan alat-alat indera penglihatan dan pendengaran. Faktor ekstern meliputi semua situasi dan kondisi lingkungan sekitar yang tidak mendukung aktivitas belajar siswa. Yang dimaksud dengan siswa yang mengalami kesulitan belajar dalam penelitian ini kesulitan belajar akademik menggunakan data Alat Ungkap Masalah (AUM PTSDL). 
Kesulitan belajar peserta didik sangat dipengaruhi perasaan dan keyakinan akan kemampuan dirinya yang rendah (efikasi diri) (Abdurrahman, 2010). Efikasi diri yang dimiliki peserta didik ikut mempengaruhi individu dalam menentukan tindakan yang akan dilakukan untuk mencapai suatu tujuan, termasuk di dalam perkiraan berbagai kejadian yang akan dihadapi. Seperti yang diungkap oleh Myres (dalam Jannah, 2013) bahwa efikasi diri yang tinggi sangat berperan dalam diri peserta didik. Siswa dengan efikasi diri yang tinggi akan memperlihatkan sikap yang lebih gigih, tidak cemas dan tidak mengalami tekanan dalam menghadapi masalah. Bandura (Widaryati, 2013) mengemukkan bahwa individu yang mempuyai efikasi diri yang rendah cenderung menyerah ketika dihadapkan pada suatu permasalahan. Selain itu akan menetapkan target yang lebih rendah dan keyakinan terhadap pencapaian target juga rendah sehingga usaha yang dilakukan lemah, cenderung menghindar bila ada tugas. Lemahnya efikasi diri dapat membuat siswa tidak mau bersaing mengejar prestasi. Padahal saat ini (pada Era Revolusi Industri 4.0) persaingan demikian ketat, dibutuhkan generasi mudah yang unggul. Keunggulan tersebut diperoleh melalui proses belajar yang optimal. Proses belajar yang optimal dapat diraih apabila efikasi diri yang dimiliki cukup. Seperti yang diungkap oleh Myres (dalam Jannah, 2013) bahwa efikasi diri yang tinggi sangat berperan dalam diri siswa. Siswa dengan efikasi diri yang tinggi akan memperlihatkan sikap yang lebih gigih, tidak cemas dan tidak mengalami tekanan dalam menghadapi masalah. Pajares dan Schunk (dalam Widaryati, 2013) mengemukakan bahwa keluarga, sekolah dan teman sebaya dapat membentuk efikasi diri individu.

Berdasarkan hal-hal tersebut penelitian dilakukan untuk memberikan pelayanan terhadap peserta didik yang dapat mempengaruhi efikasi diri sehingga hasil belajar yang sesuai potensinya dapat dicapai secara optimal. Layanan konseling kelompok untuk mengentaskan masalah siswa yang memiliki efikasi diri yang rendah tersebut diharapkan dapat membentuk efikasi diri individu agar dapat mengubah persepsi ketidakmampuan terhadap diri sendiri menjadi yakin dan mampu mengorganisasikan diri dan mengambil tindakan yang dibutuhkan sehingga akhirnya dapat membentuk perilaku yang relevan dan memperoleh hasil yang diharapkan (Andhiputra, 2011).

Nurihsan (Kunarto, 2013) menyatakan bahwa konseling kelompok adalah suatu bantuan kepada individu dalam situasi kelompok yang bersifat pencegahan dan penyembuhan, serta diarahklan pada pemberian kemudahan dalam pertumbuhan dan perkembangannya. Anggota kelompok akan belajar tentang dirinya dalam hubungannya dengan anggota lain atau orang lain. Selain itu, dalam konseling kelompok anggota kelompok dapat pula belajar memecahkan masalah berdasarkan masukan dari anggota kelompok lainnya. Konseling kelompok lebih memberikan ruang kepada individu dalam mengambil keputusan untuk mengubah tingkah laku melalui keputusan yang diambil oleh individu yang didukung oleh kesadaran yang tinggi yang pada akhirnya menciptakan perubahan tingkah lakunya.

\section{METODE}

Desain penelitian yang digunakan peneliti adalah desain penelitian eksperimen dengan jenis one-group pretest-postest design. Desain ini melibatkan satu kelompok yang diberikan pre-test $(\mathrm{O} 1)$, kemudian diberikan suatu treatment $(\mathrm{X})$ dan setelah treatment 
diberikan post test (O2). Darmadi (2011, p. 200) menyatakan keberhasilan treatment ditentukan dengan membandingkan nilai pre-test dan post-test.

Penelitian ini dilakukan terhadap siswa SMPN 1 Pondok kelapa yang terletak di Jl. Pasar Pedati Km. 10,5 Kabupaten Bengkulu tengah, Kecamatan Bengkulu Tengah yang berkesulitan belajar dengan efiksi diri rendah. Populasi penelitian ini adalah siswa kelas VIII4, VIII5, VIII6, SMPN 1 Bengkulu Tengah yang berjumlah 87 orang siswa. Sampel diambil dengan teknik purposive sampling, dengan ciri-ciri siswa yang mengalami kesulitan belajar dilihat dari data Alat Ungkap Masalah (AUM) PTSDL dan skor efikasi dirinya dalam kategori rendah. Subjek penelitan yang memenuhi kriteria adalah siswa kelas VII6 yang berjumlah 8 siswa.

Prosedur Eksperimen khususnya treatment konseling kelompok meliputi tahapantahapan: (1) Langkah Awal (a) Mengumpulan data dengan Alat Ungkap Masalah (AUM) PTSDL untuk mendapatkan sampel penelitian (siswa yang mengalami kesulitan belajar), (b) Uji coba instrumen efikasi diri untuk mengetahui validitas dan reliabilitas instrumen;

(2) Perencanan kegiatan: sasaran konseling kelompok adalah siswa yang berkesulitan belajar dari kelas VIII6. Adapun tujuan yang ingin dicapai adalah mengentaskan masalah yang dialami siswa, yaitu masalah efikasi diri yang kurang baik sehingga berkesulitan belajar. Dalam penelitian ini konseling kelompok dilakukan 5 kali pertemuan; (3) Tahap Pelaksanaan kegiatan, pada tahap ini, kegiatan berupa pemberian perlakuan kepada kelompok penelitian dalam hal ini siswa yang mengalami keslitan belajar. Namun, sebelum perlakuan terlebih dahulu diberikan instrumen angket efikasi diri(pretest).Tujuannya adalah untuk mengetahui gambaran efikasi diri siswa yang mengalami kesulitan belajar sebelum diberikan perlakuan. Hasil pre-test yang telah diperoleh dijadikan acuan sebgai dasar perbandingan dengan hasil post-test.

Rangkaian kegiatan konseling kelompok sebagai treatmen terdiri dari: (1) Tahap pembentukan meliputi kegiatan mengungkapkan pengertian dan tujuan konseling kelompok dalam rangka pelayanan bimbingan dan konseling dan saling memperkenalkan diri, serta menciptakan keakraban, (2) Tahap peralihan, yang menjelaskan kegiatan yang akan ditempuh pada tahap berikutnya, menawarkan atau mengamati apakah para anggota sudah siap menjalani kegiatan pada tahap berikutnya, dan meningkatkan keikutsertaan semua anggota kelompok, (3) Tahap kegiatan, pemimpin kelompok menyampaikan suatu masalah masing-masing dari 8 klien dalam kelompok secara tuntas dan mendalam dan anggota kelompok dapat memberikan pendapat atas topik yang dibahas dalam konseling kelompok, dan (3) Tahap pengakhiran, dalam hal ini pemimpin kelompok mengungkapkan bahwa kegiatan akan segera diakhiri, pemimpin dan anggota kelompok mengemukkan kesan dan hasil kegiatan, membahas kegiatan lanjutan, dan mengemukkan perasaan dan harapan. Perasaan pemimpin kelompok dalam tahap ini adalah tetap mengusahakan suasana hangat, bebas, dan terbuka, memberikan pernyataan dan mengucapkan terima kasih atas keikutsertaan anggota, memberikan semangat untuk melakukan kegiatan lebih lanjut, penuh rasa persahabatan, dan empati.

Tahap eksperimen selanjutnya, setelah diberikan perlakuan dilakukan post-test. Tujuannya untuk melihat perubahan signifikan setelah diberikan konseling kelompok untuk meningkatkan efikasi diri siswa. Hasil pengukuran pre-test dan posst-test akan dijadikan bahan pembanding sebelum diberikan perlakuan (konseling kelompok) dan setelah diberikan perlakuan (konseling kelompok). Selanjutnya dilakukan evaluasi kegiatan, yang difokuskan pada perkembangan pribadi yaitu efikasi diri siswa yang 
berkesukitan belajar yang meningkat, dan tindak lanjut; Pembimbing kelompok mengadakan pertemuan selanjutnya dengan anggota kelompok untuk membahas masalah-masalah yang belum terbahas pada pertemuan sebelumnya.

Data dikumpulkan dengan mnggunakan alat non-tes berupa skala efikasi diri yang sudah divalidisir (dari 48 butir yang diujicobakan) dan diberikan kepada siswa sebelum dan setelah treatmen konseling kelompok. Instrumen ini mengungkapkan indikatorindikator: (a) keoptimisan dalam menyelesaikan tugas, (b) keyakinan akan dapat mencapai tujuan, (c) kepercayaan akan kemampuan yang dimiliki, (d) prestasi yang ingin dicapai, (e) usaha yang dilakukan untuk mencapai tujuan, (f) dan rasa mampu bersosialisasi dengan lingkungan. Skala efikasi diri yang digunakan memiliki ineks diskriminasi item yang baik dengan indeks corrected item-total correlation mulai dari 0,279 sampai 0,677 (Hasil olahan program SPSS For Window Release 21). Reliabilitas skala efikasi diri menunjukkan indeks Cronbach Alpha sebesar 0,892, ini menunjukkan reliabilitas yang sangat baik.

Kesahihan AUM PTSDL diperiksa dengan mencocokan jenis-jenis masalah yang dikemukakan oleh siswa tanpa mempergunakan AUM PTSDL (yaitu dengan menuliskan masalah-masalah itu pada secarik kertas kosong) dengan masalah-masalah siswa yang sama yang dinyatakan melalui AUM PTSDL. Prosedur menuliskan jenis-jenis masalah pada kertas kosong dilakukan sebelum siswa yang bersangkutan mengisi AUM PTSDL. Dengan cara tersebut, indeks kecocokan yang diperoleh adalah 86,36 \%. Uji reliabilitas AUM PTSDL diperiksa melalui prosedur" tes-retest" dalam prosedur ini jarak pengadministrasian AUM PTSDL pengadministrasian pertama dan kedua siswa yang sama dikorelasikan. yang pertama dan yang kedua antara 2-3 hari. Skor dan jenis-jenis masalah hasil Dengan prosedur demikian itu, tingkat keterandalan yang berupa indeks korelasi skor hasil pengadministrasian yang pertama dan kedua adalah 0,76. Sedangkan tingkat kesesuaian masalah yang terungkap pada pengadministrasian pertama dan kedua adalah 0,89. Angka-angka ini memperlihatkan tingkat keterandalan AUM PTSDL.

Untuk menguji hipotesis digunakan uji non parametrik dengan rumus Wilcoxon Signed Rank dengan menggunakan SPSS (Priyanto, 2014).

Uji Wilcoxon (Uji Z) digunakan untuk menganalisis hasil-hasil pengamatan berpasangan dari dua data apakah berbeda atau tidak, adapun rumusnya sebagai berikut:

$$
Z=\frac{T-\left[\frac{1}{4 N(N+1)}\right]}{\sqrt{\frac{1}{24 N(N+1)(2 N+1)}}}
$$

Keterangan:

$\mathrm{T}=$ Jumlah ranking bertanda kecil

$\mathrm{N}$ = banyak pasang yang tidak sama nilainya

\section{HASIL DAN PEMBAHASAN}

Hasil data deskriptif menunjukkan nilai rerata efikasi diri peserta didik berkesulitan belajar adalah 88,25 dengan standar deviasi sebesar 7,2. Skor minimum 80 dan skor maksimum 97, dengan kategori sangat tinggi, tinggi, rata-rata, rendah, dan sangat rendah. Kategori kemampuan efikasi diri ditentukan berdasarkan skor total subjek pada 
pengukuran dengan menggunakan instrumen efikasi diri. Adapun data perbandingan skor efikasi diri sebelum dan setelah dilakukan treatment disajikan pada Tabel 1.

Tabel 1. Perbandingan Skor Efikasi Diri Sebelum dan Sesudah Pemberian Konseling Kelompok

\begin{tabular}{cccccc}
\hline Responden & Pre-test & Kategori & Pre-test & Kategori & Peningkatan \\
\hline Ga & 97 & Tinggi & 112 & $\begin{array}{l}\text { Sangat } \\
\text { Tinggi }\end{array}$ & 15 \\
\hline Aw & 95 & Tinggi & 110 & $\begin{array}{l}\text { Sangat } \\
\text { Tinggi }\end{array}$ & 15 \\
\hline Sa & 80 & $\begin{array}{c}\text { Sangat } \\
\text { Rendah }\end{array}$ & 102 & $\begin{array}{l}\text { Sangat } \\
\text { Tinggi }\end{array}$ & 22 \\
\hline Nr & 88 & Rata-rata & 108 & $\begin{array}{l}\text { Sangat } \\
\text { Tinggi }\end{array}$ & 20 \\
\hline Nd & 81 & $\begin{array}{c}\text { Sangat } \\
\text { Rendah }\end{array}$ & 105 & $\begin{array}{l}\text { Sangat } \\
\text { Tinggi }\end{array}$ & 24 \\
\hline Ak & 89 & Rata-rata & 106 & $\begin{array}{l}\text { Sangat } \\
\text { Tinggi }\end{array}$ & 17 \\
\hline Sp & 96 & Tinggi & 103 & $\begin{array}{l}\text { Sangat } \\
\text { Tinggi }\end{array}$ & 7 \\
\hline Ao & 80 & $\begin{array}{c}\text { Sangat } \\
\text { Rendah }\end{array}$ & 104 & $\begin{array}{l}\text { Sangat } \\
\text { Tinggi }\end{array}$ & 24 \\
\hline Rata-rata & $\mathbf{8 8}$ & Rata-rata & $\mathbf{1 0 6 , 2 5}$ & $\begin{array}{l}\text { Sangat } \\
\text { Tinggi }\end{array}$ & $\mathbf{1 5 , 5}$ \\
\hline
\end{tabular}

Tabel 1 menunjukkan adanya kenaikan skor efikasi diri dari sebelum diberikan perlakuan (pretest) dengan nilai rata-rata skor=88berada pada kategori rata-rata dibandingkan sesudah diberikan konseling kelompok ( post-test) dengan nilai rata-ratas kor efikasi diri sebesar 106,25. Nilai rata-rata pretest 88 dengan kategori rata-rata terjadi kenaikan nilai skor pada posttest menjadi 106,25 dengan kategori sangat tinggi. Hasil uji $\mathrm{Z}$ menunjukkan Nilai $\mathrm{Z}=-2,527$ dengan nilai Sig. (2 tailed) sebesar 0,012 ( $\mathrm{p}<0,05$ maka hipotesis (H0) ditolak, sehingga dapat disimpulkan bahwa ada pengaruh layanan konseling kelompok terhadap efikasi diri siswa berkesulitan belajar. Kesulitan belajar terhadap efikasi diri siswa sebelum diberikan layanan konseling kelompok memiliki skor sangat rendah terlihat dari hasil skor angket pretest yang tergolong dalam kategori sangat rendah. Dari hasil pengkategorian skor tesebut diperoleh 8 orang siswa yang akan diberikan layanna konseling kelompok. Pemberian layanan konseling kelompok diberikan sebanyak delapan kali pertemuan, Pemberian layanan konseling kelompok yang telah diberikan bertujuan agar delapan orang siswa tersebut dapat memiliki efikasi yang tinggi dalam mengatasi kesulitan afektif dalam belajar.

Pajares dan Schunk (dalam Widaryati, 2013) mengemukakan bahwa keluarga, sekolah dan teman sebaya dapat membentuk efikasi diri individu. Berdasarkan hal-hal tersebut penting mencari bentuk kegiatan yang dapat mempengaruhi efikasi diri.Kegiatan tersebut diharapkan dapat membentuk efikasi diri individu agar dapat mengubah presepsi ketidakmampuan terhadap diri sendiri menjadi yakin dan mampu mengorganisasikan diri dan mengambil tindakan yang dibutuhkan sehingga akhirnya dapat membentuk perilaku yang relevan dan memperoleh hasil yang diharapkan. Hasil penelitian mengkonfirmasi pandangan Nurihsan (Kunarto, 2013:7) yang menyatakan bahwa konseling kelompok adalah suatu bantuan kepada individu dalam situasi kelompok yang bersifat pencegahan dan penyembuhan, serta diarahklan pada pemberian kemudahan dalam pertumbuhan dan perkembangannya keyakinan akan kemampuan dirinya. Penelitian ini juga menegaskan bahwa kesulitan belajar siswa dipengaruhi oleh efikasi diri. Alwisol (dalam Kusrieni, 2014:107) menyatakan bahwa efikasi diri adalah 
persepsi diri sendiri mengenai seberapa bagus diri dapat berfungsi dalam situasi tertentu. Efikasi diri berhubungan dengan keyakinan bahwa dirinya memiliki kemampuan melakukan tindakan yang diharapkan. Efikasi diri adalah pertimbangan seseorang terhadap kemampuan dirinya untuk mengorganisasi dan menampilkan tindakan yang diperlukan dalam mencapai tujuan yang diinginkan, tidak tergantung pada jenis keterampilan dan keahlian tetapi lebih berhubungan dengan keyakinan tentang apa yang dapat dilakukan dengan berbekal keterampilan dan keahlian.Seperti yang diungkap oleh Myres (dalam Jannah, 2013) bahwa efikasi diri yang tinggi sangat berperan dalam diri peserta didik. Siswa dengan efikasi diri yang tinggi akan memperlihatkan sikap yang lebih gigih, tidak cemas dan tidak mengalami tekanan dalam menghadapi masalah.

Menurut Feist dan Feist ( 2010, p. 213) ada 4 faktor yang mempengaruhi perkembangan efikasi diri pada seseorang: (a). Pengalaman menguasai sesuatu (mastery experiences).Menurut Bandura (dalam Feist dan Feist, 2010:214) pengalaman menguasai sesuatu atau mastery experiences adalah faktor yang paling mempengaruhi efikasi diri pada diri seseorang. Keberhasilan akan mampu meningkatkan ekspektasi tentang kemampuan, sedangkan kegagalan cenderung menurunkan hal tersebut. (b) Permodelan sosial (social modelling); kesuksesan atau kegagalan orang lain sering digunakan sebagai pengukur kemampuan dari diri seseorang. Efikasi diri dapat meningkat saat mengobservasi keberhasilan seseorang yang mempunyai kompetensi setara, namun efikasi diri dapat berkurang ketika melihat orang lain yang setara gagal. Secara umum. Pemodelan sosial juga dapat diperoleh dalam dinamika kelompok konseling kelompok.(c). Persuasi sosial (social persuasion) dapat meningkatkan atau menurunkan efikasi diri, dan harus pada kondisi yang tepat. Kondisi tersebut adalah bahwa seseorang haruslah mempercayai pihak yang melakukan persuasi karena kata-kata dari pihak yang terpercaya lebih efektif daripada kata-kata dari pihak yang tidak terpercaya. Persuasi sosial paling efektif ketika dikombinasikan dengan performa yang sukses. Persuasi mampu meyakinkan seseorang untuk berusaha jika performa yang dilakukan terbukti sukses. (d) Kondisi fisik dan emosional (physical and emotional states). Ketika seseorang mengalami ketakutan, kecemasan yang kuat dan stress yang tinggi memungkinkan seseorang akan memiliki efikasi diri yang rendah, sehingga emosi yang kuat cenderung untuk mengurangi performa seseorang. Pertemuan pertama sampai pertemuan kedelapan membahas masalah yang dialami 8 orang siswa yang menunjukkan terdapat beberapa siswa dengan efikasi diri yang sangat rendah. Rendahnya kemampuan efikasi diri siswa disebabkan oleh beberapa faktor, seperti kurang yakin akan kemampuan yang dimiliki (tidak percaya diri), rasa takut, kecewa, kegagalan dapat menurunkan efikasi diri ketika seseorang merasa sudah memberikan usaha yang terbaik, kegagalan akan berdampak sedikit pada efikasi diri seseorang, terutama pada mereka yang memiliki ekspektasi kesuksesan yang tinggi.

\section{SIMPULAN}

Terdapat pengaruh layanan konseling kelompok terhadap efikasi diri peserta didik berkesulitan belajar terlihat dari hasil uji $Z=-2.527(p<0,05)$, terdapat perbedaan yang signifikan skor rata-rata efikasi diri sebelum diberikan konseling kelompok dibandingkan setelah diberikan konseling kelompok. Nila $Z$ yang negatif menunjukkan adanya kenaikan skor efikasi diri setelah diberikan konseling kelompok. 
Direkomendasikan ke depannya peserta didik diharapkan untuk terus meningkatkan efikasi diri agar dapat mengubah presepsi ketidakmampuan terhadap diri sendiri menjadi yakin dan mampu mengorganisasikan diri dan mengambil tindakan yang dibutuhkan sehingga akhirnya dapat membentuk perilaku yang relevan dan memperoleh hasil yang diharapkan. Maka, diharapkan sekolah terkhusus guru BK dapat membantu untuk meningkatkan kegiatan pemberian layanan konseling kelompok agar dapat membantu siswa dalam mengentaskan masalah yang berkaitan dengan masalah pribadi siswa. Sekolah diharapkan dapat mendukung semua kegiatan layanan bimbingan dan konseling terutama kegiatan konseling kelompok yang dilakukan oleh guru pembimbing. Bagi peneliti selanjutnya, dapat menggunakan penelitian ini sebagai bahan acuan untuk mengembangkan penelitian selanjutnya yang terkait dengan pengembangan efikasi diri peserta didik berkesulitan belajar. Selain itu, diharapkan dapat melakukan penelitian yang sama dengan metode yang berbeda agar penelitan menjadi luas.

\section{REFERENSI}

Abdurrahman, M. (2010). Pendidikan bagi anak berkesulitan belajar. Jakarta: Rineka Cipta.

Andhiputra, N .A .A . (2015). Konseling kelompok; Perspektif teori dan aplikasi. Yogyakarta: Media Akademik.

Darmadi, H. (2011). Metode penelitian pendidikan. Bandung: Alfabeta.

Djamarah, S. B. (2015). Psikologi belajar. Jakarta: Rineka Cipta.

Feist, J. \& Fiest, G. J. (2010). Teori kepribadian (Penterjemah Smitha Prathita S.). Jakarta: Salemba Humatika.

Gunawan, A. (2014). Pendidikan di Indonesia. Jakarta: Raja Grafindo Persada.

Ihsan, F. (2008). Dasar-dasar Kependidikan. Jakarta: Rineka Cipta.

Jannah, E. U. (2013). Hubungan antara self-efficacy dan kecerdasan emosional dengan kemandirian pada remaja. Persona: Jurnal Psikologi Indonesia, 2(3), 278-287.

Kurnanto, E. M. (2013). Konseling kelompok. Bandung: Alfabeta.

Kusrieni, D. (2014). Hubungan efikasi diri dengan perilaku menyontek. PSIKOPEDAGOGIA Jurnal Bimbingan dan Konseling, 3(2), 101-110.

Priyanto, D (2014). SPSS 22: Pengolahan data praktis.Yogyakarta: Andi Offset

Syah, M. (2007). Psikologi pendidikan: dengan pendekatan baru. Bandung: Remaja Rosdakarya.

Tohirin. (2015). Bimbingan dan konseling di sekolah dan madrasah berbasis integrasi. Jakarta: Raja Grafindo Persada.

Widaryati, S. (2013). Efektivitas pengaruh konseling kelompok terhadap efikasi diri siswa SMA. PSIKOPEDAGOGIA Jurnal Bimbingan dan Konseling, 2(2), 25-31.

Yusuf, S,. \& Nurihsan, J. A. (2010). Landasan bimbingan dan konseling. Bandung: Remaja Rosdakarya. 